\title{
25. QUARTZ CONTENT OF NORTHWEST PACIFIC HOLE 576A AND IMPLICATIONS FOR CENOZOIC EOLIAN TRANSPORT ${ }^{1}$
}

\author{
Margaret Leinen, University of Rhode Island ${ }^{2}$
}

\begin{abstract}
The amount and the accumulation rate of quartz were measured in 33 samples from Hole 576A. The amount and source of mineral aerosol being deposited in the northwest Pacific during the Cenozoic are evaluated using these data. When Hole 576A is compared to a Cenozoic record in the central North Pacific, a strong uniformity in the composition of the mineral aerosol across the North Pacific is seen. The data suggest that Hole 576A entered the influence of the westerlies about $15 \mathrm{~m} . \mathrm{y}$. ago and that since that time the rates of sediment deposition have increased. Only the dramatic change in quartz accumulation $2.5 \mathrm{~m}$.y. ago can be clearly related to a climatic event, but a gradual increase in quartz accumulation through the Miocene and early Pliocene is probably a result of increasing Northern Hemisphere aridity and intensified atmospheric activity associated with global cooling during the interval.
\end{abstract}

\section{INTRODUCTION}

Since quartz does not precipitate authigenically in the deep sea, variations in its accumulation rate in unlithified oceanic sediments must result from changes in detrital sedimentation. At sites remote from land and protected from turbidite deposition, the quartz content of sediments reflects eolian transport of terrigenous mineral aerosol to the oceans (Rex and Goldberg, 1958; Rex et al., 1969; Windom, 1969, 1975). The distribution of quartz in surface sediments mirrors present-day atmospheric circulation patterns (Heath et al., 1973; Kolla and Biscaye, 1977; Molina-Cruz and Price, 1977; Thiede, 1979), and its variation in Pleistocene sediments has been shown to reflect changes in wind intensity, wind-belt position, and continental weathering in areas removed from the influence of continental runoff and transport down the continental slope in areas closer to shore (Kolla and Biscaye, 1977; Pisias and Leinen, 1983; Schramm, 1983).

Only one long, continuous, and unequivocally eolian pre-Pleistocene record of deep-sea quartz content has been available previously to study Cenozoic eolian deposition in the Pacific Ocean (Core LL44-GPC3, Leinen and Heath, 1981). Without others it has been difficult to evaluate the relative importance of changing rates of eolian input and changing composition of mineral aerosol from changes in deposition due to migration of the site into and out of wind belts (caused by rotation of the Pacific plate).

By examining the long, continuous red-clay sediment record from Hole 576A, we can constrain the previous models of Cenozoic eolian deposition in the North Pacific. Site 576 is presently located at $32^{\circ} 21.4^{\prime} \mathrm{N}$, $164^{\circ} 16.5^{\prime} \mathrm{E}$, beneath the core of the Northern Hemisphere westerlies (Fig. 1). About $53 \mathrm{~m}$ of pelagic clay overlying about $13 \mathrm{~m}$ of interbedded Late Cretaceous carbonate turbidites and pelagic clay were recovered from

\footnotetext{
${ }^{1}$ Heath, G. R., Burckle, L. H., et al., Init. Repts. DSDP, 86: Washington (U.S. Govt. Printing Office).

2 Address: Graduate School of Oceanography, University of Rhode Island, Narragansett, RI 02882 .
}

Hole 576A. A companion hole, Hole 576, terminated on chert at $76 \mathrm{~m}$. The uppermost clays are yellowish brown and slightly silty. Below about $12 \mathrm{~m}$ the clays are dark brown, finer grained, and somewhat "slick" when cut. The lithologic column from Hole 576A is very similar to, but thicker than, that recovered in a long piston core, Core LL44-GPC3, from the central North Pacific. Thus, the quartz content of Hole 576A can be used to study Cenozoic eolian deposition in the western North Pacific.

\section{METHODS}

The quartz content of 33 samples from Hole 576A was measured using a modification of the techniques of Till and Spears (1969) and Ellis and Moore (1973). Freeze-dried samples were leached with acetic acid buffered to $\mathrm{pH} 5.6$ with sodium acetate to remove calcium carbonate. This procedure and subsequent washing of the sample in deionized water also removed sea salt from interstitial pore water in the sample. An amount of alpha $\mathrm{Al}_{2} \mathrm{O}_{3}$ equal to one-half the sample weight was added to each sample as an internal standard. The samples were ground for $2 \mathrm{hr}$. in an automatic mortar and pestle to achieve a uniform grain size, dried, and fired at $1000^{\circ} \mathrm{C}$ in alumina crucibles for 24 hr. to eliminate interference caused by clay minerals. The samples were subsequently ground briefly in alumina mortars under acetone and the dried, powdered samples were pressed into duplicate $\mathrm{X}$-ray planchettes using 40-mesh granulated zinc as a backing medium. The samples were Xrayed on a Phillips diffractometer using Ni-filtered, monochromatized CuK alpha radiation at $45 \mathrm{kV}$ and $35 \mathrm{~mA}$. Each sample was scanned from $25.11^{\circ}$ to $25.94^{\circ} 2 \theta$ at $0.004^{\circ} 2 \theta / \mathrm{s}(200 \mathrm{~s})$ over the $3.48-\AA$ ( 012$)$ alumina peak and from $26.17^{\circ}$ to $27.00^{\circ} 2 \theta$ at the same rate and for the same time interval over the 3.34-A (101) quartz peak. To correct the X-ray peaks for background, 200-s background counts were made at $25^{\circ}, 26^{\circ}$, and $27^{\circ} 2 \theta$. The total X-ray counts over the 200 -s intervals were collected digitally by an interfaced microprocessor and used to calculate peak areas of alumina and quartz. The ratio of quartz/alumina peak areas was converted to weight percent quartz in the sample by reference to a calibration curve determined by standard additions of quartz to a central North Pacific red clay from 2500 to $2550 \mathrm{~cm}$ depth in Core LL44-GPC3 that has been homogenized and is used as a standard for geochemical and mineralogical analyses in our laboratory.

\section{RESULTS AND DISCUSSION}

\section{Quartz Content of Hole 576A Samples}

The quartz contents of Hole 576A samples are listed in Table 1. The average of the duplicate determinations of quartz concentration is plotted versus depth in Fig- 


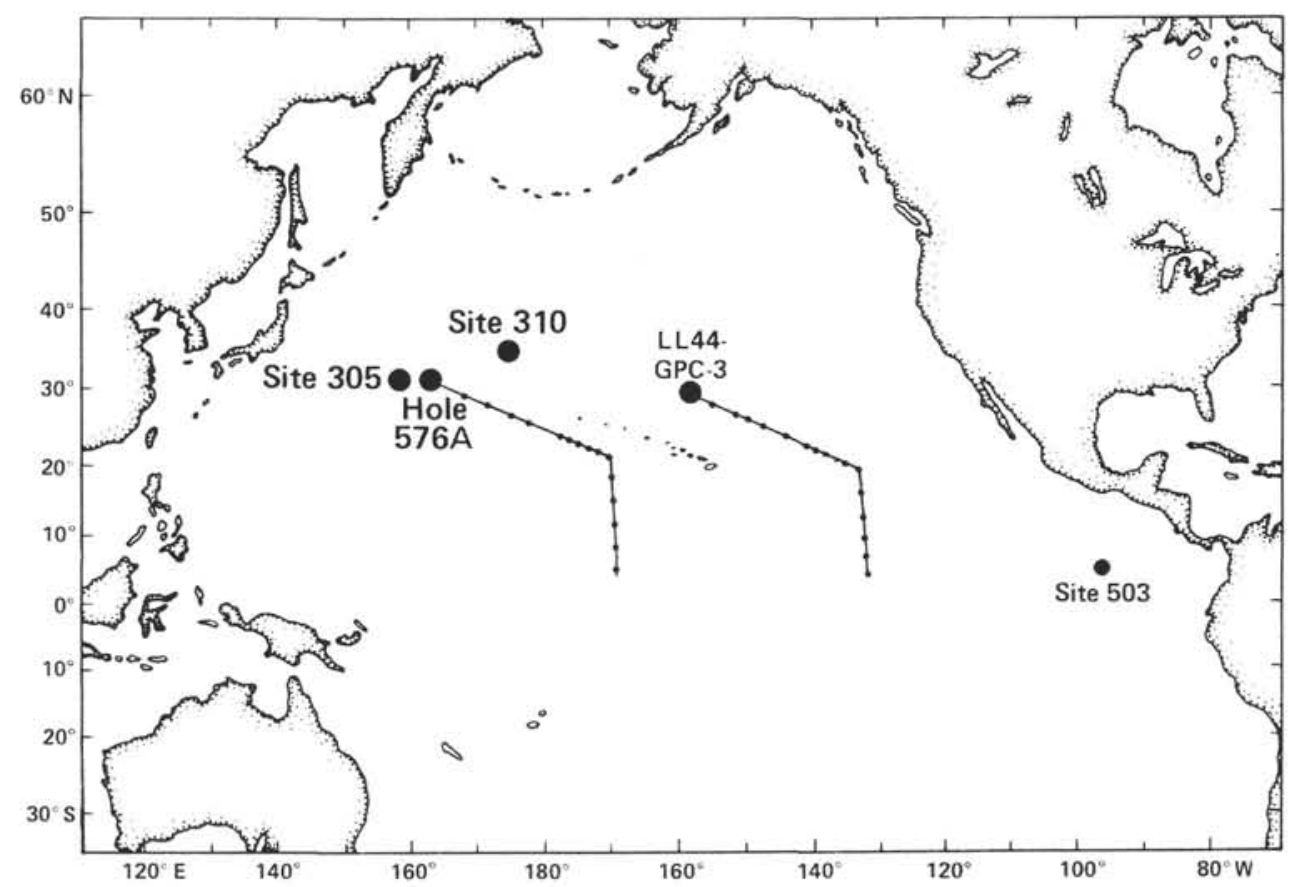

Figure 1. Location of DSDP Hole 576A and Core LL44-GPC-3. DSDP Sites 305, 310, and 503 are also shown. The backtrack paths along which the sites traveled in response to seafloor spreading are also shown. Dots along these paths correspond to 5 -m.y. time intervals. $20^{\circ} \mathrm{N}$ latitude is the approximate present-day boundary between the Northern Hemisphere westerlies and northeast trade winds.

Table 1. Quartz content of Hole 576A samples.

\begin{tabular}{|c|c|c|c|c|}
\hline \multirow{2}{*}{$\begin{array}{l}\text { Core-Section } \\
\text { (interval in } \mathrm{cm} \text { ) }\end{array}$} & \multirow{2}{*}{$\begin{array}{l}\text { Sub-bottom } \\
\text { depth }(\mathrm{cm})\end{array}$} & \multicolumn{3}{|c|}{ Quartz (wt.\%) } \\
\hline & & 1 & 2 & Average \\
\hline $1-1,21-25$ & 23 & 16.94 & 16.31 & 16.63 \\
\hline $1-3,81-85$ & 383 & 18.39 & 17.82 & 18.11 \\
\hline $1-6,80-83$ & 831 & 15.57 & 15.48 & 15.52 \\
\hline $2-3,47-50$ & 1219 & 17.79 & 16.91 & 17.35 \\
\hline $3-1,47-50$ & 1869 & 13.05 & 13.06 & 13.06 \\
\hline $3-3,70-73$ & 2191 & 8.46 & 9.27 & 8.87 \\
\hline $3-4,117-120$ & 2389 & 11.20 & 12.11 & 11.66 \\
\hline $3-5,127-130$ & 2549 & 9.07 & 8.97 & 9.02 \\
\hline $3-6,110-113$ & 2681 & 14.05 & 15.23 & 14.64 \\
\hline $4-1,50-53$ & 2821 & 10.91 & 10.93 & 10.92 \\
\hline $4-2,103-106$ & $3025^{*}$ & 8.62 & 8.52 & 8.57 \\
\hline $4-3,98-101$ & 3169 & 6.02 & 5.60 & 5.81 \\
\hline $4-4,104-107$ & 3325 & 5.81 & 5.91 & 5.86 \\
\hline $4-5,20-23$ & 3391 & 4.36 & 4.15 & 4.25 \\
\hline $4-6,60-63$ & 3581 & 5.16 & 5.47 & 5.31 \\
\hline $5-1,87-90$ & 3809 & 5.17 & 5.15 & 5.16 \\
\hline $5-2,40-43$ & $3911^{*}$ & 1.68 & 1.84 & 1.76 \\
\hline $5-3,30-33$ & 4051 & 2.64 & 2.63 & 2.64 \\
\hline $5-5,137-140$ & 4459 & 4.72 & 4.63 & 4.67 \\
\hline $5-6,130-133$ & 4601 & 2.85 & 2.91 & 2.88 \\
\hline $5-7,25-28$ & 4646 & 6.22 & 6.14 & 6.18 \\
\hline $6-1,90-93$ & 4761 & 3.92 & 4.00 & 3.96 \\
\hline $6-2,47-50$ & 4869 & 4.35 & 4.06 & 4.21 \\
\hline $6-3,93-96$ & $5065^{*}$ & 4.74 & 4.87 & 4.81 \\
\hline $6-4,11-14$ & 5132 & 6.29 & 5.95 & 6.12 \\
\hline $6-5,12-15$ & 5283 & 5.46 & 5.36 & 5.41 \\
\hline $6-5,127-130$ & 5399 & 4.54 & 4.54 & 4.54 \\
\hline $6-6,17-20$ & 5439 & 5.53 & 5.05 & 5.29 \\
\hline $6-7,22-25$ & 5593 & 4.03 & 3.80 & 3.91 \\
\hline $7-1,137-140$ & 5759 & 4.18 & 4.14 & 4.16 \\
\hline $7-2,22-25$ & 5793 & 5.48 & 5.51 & 5.50 \\
\hline $7-3,17-20$ & 5939 & 7.15 & 5.77 & 6.46 \\
\hline $7-3,35-38$ & 5946 & 3.51 & & 3.51 \\
\hline
\end{tabular}

Note: All sub-bottom depths were calculated by G. R. Heath on the basis of correlation with Holes 576 and $576 \mathrm{~B}$. Samples with asterisks are from intervals that show some evidence of flow-in. ure 2. The sample spacing in the upper portion of the core was intentionally larger than that in the middle and lower portion of the core because it was anticipated that sedimentation rates for the upper (late Neogene) portion of the sedimentary record would be much greater than those for earlier time intervals.

\section{Comparison of Hole 576A and Core LL44-GPC3 Quartz Content}

Also plotted for comparison on Figure 2 is the quartz content of samples from Core LL44-GPC3, the central North Pacific $\left(30^{\circ} 19.9^{\prime} \mathrm{N}, 157^{\circ} 49.9^{\prime} \mathrm{W}\right)$ red clay core that has been used by Leinen and Heath (1981) to infer Cenozoic eolian deposition. The age at the bottom of Core LL44-GPC3 is roughly equivalent to that at the base of Hole 576A.

The stratigraphy for Core LL44-GPC3 has been revised and additional quartz-content determinations have been made since it was first published. The original stratigraphy was based on paleomagnetic reversal stratigraphy in the upper $4 \mathrm{~m}$ (2.47 m.y. ago) of the core (Prince et al., 1980) and ichthyolith stratigraphy for the remaining $20 \mathrm{~m}$ of the core (Doyle and Riedel, 1979). Additional ichthyolith age determinations (Doyle, 1980) and identification of an Ir anomaly associated with the Cretaceous/Tertiary boundary (Kyte and Wasson, in press) have resulted in a new stratigraphy that is discussed in detail in Leinen and Heath (in press) and is used in this chapter. The stratigraphy for Hole 576A is based on correlation with that of Holes 576 and 576B. Holes 576 and $576 \mathrm{~B}$ were dated using paleomagnetic reversal stratigraphy (Heath et al., 1983; Heath, Rea, and Levi, this volume), ichthyolith stratigraphy (Doyle, 1983; Doyle and 

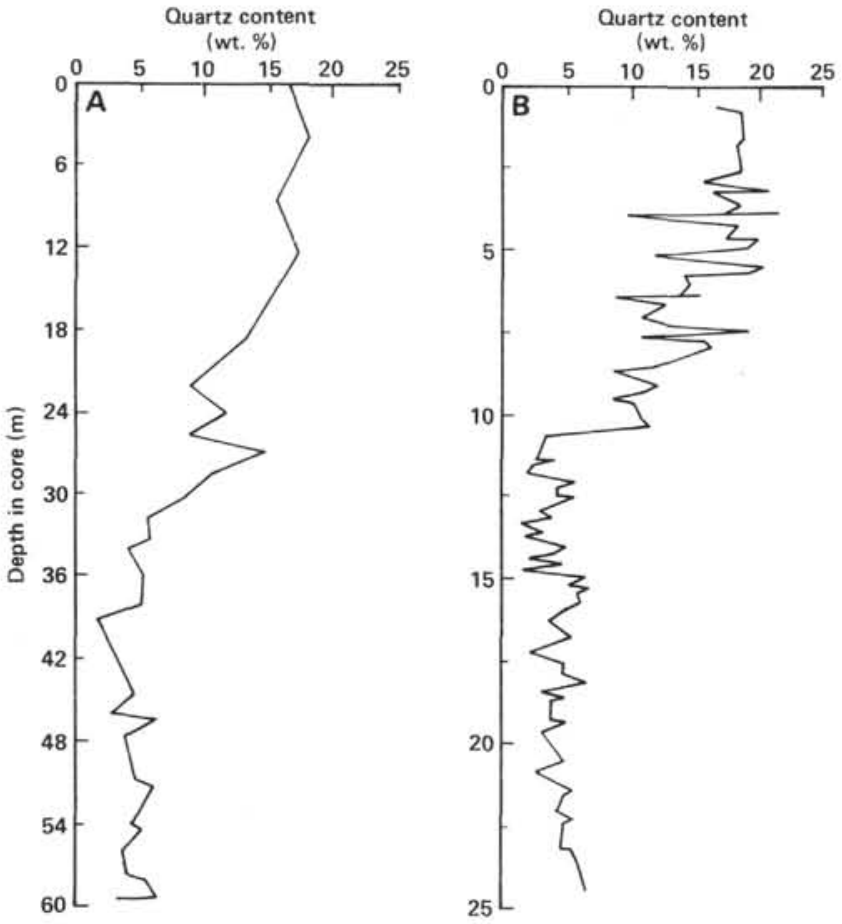

Figure 2. Quartz contents of (A) Hole 576A and (B) Core LL44-GPC-3 in weight percent plotted versus depth in core. (All data are calcium carbonate and biogenic opal-free values.) Because of differences in sedimentation rates, the plots are essentially age equivalent (i.e., bottom of both cores are approximately time equivalent).

Riedel, this volume), and nannofossil stratigraphy for the interbedded pelagic clay and carbonate turbidite section.

The remarkable similarity of the two North Pacific quartz records is less striking when they are plotted versus age rather than depth in the core (Fig. 3). Plotted versus age, the absolute amount of quartz in the sediments and the time series of quartz variation are very similar for all but the Miocene and early Pliocene (2.522 m.y. ago) portions of the record. A major difference in the stratigraphies of the two sediment columns is the lack of a stable magnetic signal for paleomagnetic reversal stratigraphy below about $4 \mathrm{~m}(2.47 \mathrm{~m}$.y. ago $)$ in Core LL44-GPC3. This has been attributed to a decrease in the ratio of stable detrital magnetic minerals to unstable authigenic iron oxide and oxyhydroxides (Prince et al., 1980; Heath et al., 1983; Heath, Rea, and Levi, this volume). Thus, although high-quality magnetic-reversal stratigraphy is available back to the Miocene in Holes 576 and 576B, it ends in the early Pliocene in Core LL44GPC3. This factor is important in evaluating the differences between the temporal quartz record at the two sites during the Miocene and Pliocene epochs. Ichthyolith age determinations for Holes 576 and 576B are quite different from paleomagnetic ages in the Miocene sediments (Doyle, 1983; Doyle and Riedel, this volume). To evaluate the effect of this difference on the quartz curves in Figure 3, a second temporal quartz record is plotted (dotted line) based on paleomagnetic stratigraphy to 2.47 m.y. ago (Heath, Rea, and Levi, this volume) and on ichthyolith ages for the rest of the hole. Obviously, the superior paleomagnetic data indicate this alternate stra-

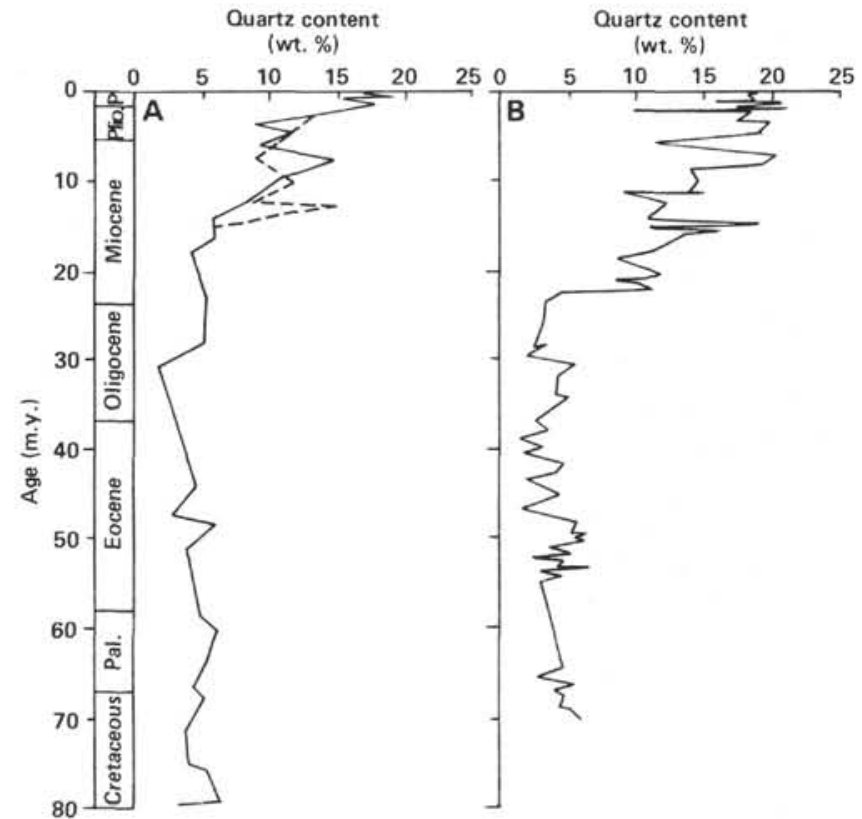

Figure 3. Quartz content of (A) Hole 576A and (B) Core LL44-GPC-3 in weight percent plotted versus age. All data are calcium carbonate and biogenic opal-free values. Dotted line on the curve for Hole $576 \mathrm{~A}$ indicates age determinations for the Miocene Epoch based solely on ichthyolith stratigraphy.

tigraphy is wrong. However, we can see from this curve that the differences between the two sites during the Miocene are at least partly a function of stratigraphy.

In spite of uncertainties in the Miocene, a comparison of the quartz-content curves from Hole 576A and Core LL44-GPC 3 suggests long-term changes in the abundance of mineral aerosol being carried to the North $\mathrm{Pa}$ cific. In order to determine whether any of these changes are solely caused by the position of the sites with respect to the major wind belts, the sites have been rotated along the paths they have followed as a result of seafloor spreading from Pacific spreading centers. The rotation model used was developed by Prince (1978) and Prince et al. (1980) and is very similar to that of van Andel et al. (1975). The backtrack paths are indicated on Figure 1. Because the sites are at nearly the same latitude, their temporal positions relative to the margin of Northern Hemisphere westerlies are very similar.

Leinen and Heath (1981) interpreted the large change in quartz content of Core LL44-GPC 3 at roughly 23 m.y. ago as a result of rotation of that core site into the westerlies. They also found a difference in the chemistry of the sediments (quartz/A1 ratio) and in the mineralogy (quartz/illite) before and after the change in quartz content. They attributed both to a change in source material from quartz-poor, more basic dust transported from the developing western North American cordillera by the trade winds before the Miocene to more quartz-rich, acidic material from the Asian continent after the site rotated into the westerlies. Although the general features of this model are confirmed by Hole 576A, the details remain unclear because of the stratigraphic uncertainty. The Neogene increase in quartz content from 5 to $14 \%$ 
in Hole 576A occurs gradually between 8 and 18 m.y. ago, $5 \mathrm{~m}$.y. after the dramatic increase in quartz content in Core LL44-GPC3 23 m.y. ago. Both stratigraphies suggest that the gradual increase in quartz content in Hole $576 \mathrm{~A}$ is correlated with the gradual increase between 8 and $22 \mathrm{~m}$.y ago, not with the sharp increase at 23 m.y. ago in Core LL44-GPC3. The sites are at similar latitudes, and their angle of rotation along the backtrack paths is very flat relative to lines of latitude. Therefore, the sites must have traveled north at a rate of about $1^{\circ}$ latitude $/ 5 \mathrm{~m}$.y. during the Neogene period. The southern margin of material deposited from the westerlies is very sharp (Moore and Heath, 1978). The difference in timing of the major quartz increase ( $23 \mathrm{~m}$.y. ago in Core LL44-GPC3 vs. 18 m.y. ago in Hole 576A) could therefore be because of the small difference in their latitudes $\left(1^{\circ} 1.5^{\prime}\right)$. Thus, the rotation data do not help to constrain the ambiguities in age of the large increase in quartz content at the sites. Both records are very similar prior to $30 \mathrm{~m} . \mathrm{y}$. ago and suggest great uniformity in the source and nature of mineral aerosol being deposited across the North Pacific during the early Tertiary.

\section{Implications of Quartz Content for Depositional Processes}

It has been assumed that the mineral aerosol injected into the atmosphere has a complicated vertical distribution and undergoes complex mixing and depositional processes near its site of injection (Windom, 1975). It has further been assumed that these mixing and depositional processes continue over continents and the ocean/ continent boundary (Windom, 1975; Pewe et al., 1981). This is confirmed by a growing number of studies of present-day dust storms (e.g., Gillette, 1981; McCauley et al., 1981; Pewe et al., 1981). Once injected into the stratosphere and transported over the oceans, the mineral aerosol is assumed to achieve some sort of equilibrium grain-size distribution (Windom, 1975; Rea and Janecek, 1982; Janecek and Rea, in press); the grain size of material deposited from this equilibrium assemblage is representative of the average atmospheric circulation "intensity" or "vigor" (e.g., Parkin, 1974; Parkin and Padgham, 1975). These assumptions have implications for the mineralogy of the aerosol: since clay minerals are concentrated in the smaller size fractions and siltsized particles are enriched in quartz and feldspars (e.g., Griffin et al., 1968), changes in grain size along a dust storm or dust transport trajectory should result in changes in the mineral assemblage along the trajectory. Thus, only the assumption of an "equilibrium" grain-size assemblage allows the direct comparison of quartz contents from cores at different distances from the continent. This assumption is especially important of paleoclimatic studies of Cenozoic sediments, such as those of Rea and his co-workers (Rea and Janecek, 1982) since they were forced to compare grain-size data from a small number of widely separated drilling locations, all of which had incomplete sedimentary records.

Recent work by Dauphin (1983) has suggested that the assumption of a uniform "equilibrium" grain-size distribution across the central Pacific wind belts is in- correct. He analyzed the grain size of only the quartz in the surface sediments to insure that he was not looking at material formed authigenically or transported to the sample sites by other means. His analyses show a linear decrease in quartz grain size from $10.3 \mathrm{~m}$ to $7.3 \mu \mathrm{m}$ across $7000 \mathrm{~km}$ in the North Pacific. These results suggest a nonequilibrium mineral aerosol and imply that mineralogy might also change with distance. Although finegrained, the quartz was concentrated in the silt range $(2-20 \mu \mathrm{m})$ rather than in the clay range $(<2 \mu \mathrm{m})$. Studies by Rea and his co-workers and studies of presently accumulating mineral aerosols (Rea and Janecek, 1982; R. A. Duce, personal communication, 1984) suggest that the average size of North Pacific dust is in the clay range. Unless all of this material is deposited as aggregates, Dauphin's (1983) grain-size data may not be representative of the bulk of the mineral aerosol. If particles are transported as aggregates, techniques that include grainsize analysis of clay particles that have become disaggregated are not representative.

The uniformity of quartz concentration between Hole 576A and Core LL44-GPC3 (Fig. 2) suggests a very homogeneous mineral aerosol composition across $5000 \mathrm{~km}$ of the North Pacific. Although this might also be inferred from the fairly uniform quartz and illite content of surface sediments in samples analyzed by Heath and his co-workers (Moore and Heath, 1978; Heath and Pisias, 1979), the two cores discussed here established that this has been the case for most, if not all of the Cenozoic Era.

\section{Quartz Accumulation Rates}

Changes in the quartz content of deep-sea sediments in the North Pacific have been attributed primarily to changes in the mineral assemblage resulting from different source regions (Leinen and Heath, 1981). The mass accumulation of quartz in the sediments is influenced by source regions, but is also influenced by the proximity of source regions, the amount of material available for transport, and the vigor of long-distance transport. The last factor is probably a complex function of the mean atmospheric circulation intensity and the intensity of the large storms that transport the bulk of mineral aerosol carried to the oceans (e.g., Duce et al., 1980; Gillette, 1981). If differences caused by the proximity of a depositional site can be evaluated, the remaining record should contain a paleoclimatic signal. The two sites discussed here, because of their similar source regions and latitudinal positions, provide a unique opportunity to evaluate the differences in quartz accumulation caused by distance along a transport path.

Mass sediment-accumulation rates for the two sediment columns have been constructed using the paleomagnetic reversal stratigraphies and ichthyolith stratigraphies, together with bulk-density data (Table 2 ). The mass sediment-accumulation rate is $R=\rho S$ where $\rho$ is the dry-bulk density in $\mathrm{g} / \mathrm{cm}^{3}$ and $S$ is the linear sedimentation rate between two datums in $\mathrm{cm} / \mathrm{m}$.y. Quartz accumulation rates (Table 3, Fig. 4) were calculated from the mass sediment-accumulation rates and the analytical quartz percentages. The quartz accumulation rate record 
Table 2. Mass sediment-accumulation rates of Hole 576A samples and parameters used for their calculation.

\begin{tabular}{|c|c|c|c|c|}
\hline $\begin{array}{l}\text { Sample depth } \\
\text { (cm) }\end{array}$ & $\begin{array}{c}\text { Water content } \mathrm{t}^{\mathrm{a}} \\
(\%)\end{array}$ & $\begin{array}{l}\text { Dry-bulk } \\
\text { density } \\
\left(\mathrm{g} / \mathrm{cm}^{3}\right)\end{array}$ & $\begin{array}{l}\text { Sedimentation } \\
\text { rate }^{c^{c}} \\
(\mathrm{~cm} / \mathrm{m} \cdot \mathrm{y} .)\end{array}$ & $\begin{array}{c}\text { Mass accumulation } \\
\text { rate }^{\mathrm{d}} \\
\left(\mathrm{g} / \mathrm{cm}^{2} / \mathrm{m} . \mathrm{y}\right)\end{array}$ \\
\hline 245 & 60.47 & 1.035 & 1377 & 1425 \\
\hline 452 & 62.41 & 1.008 & 1377 & 1388 \\
\hline 727 & 62.55 & 1.022 & 1194 & 1220 \\
\hline 754 & 63.64 & 0.978 & 1194 & 1168 \\
\hline 767 & 66.89 & 0.911 & 794 & 1088 \\
\hline 1025 & 69.04 & 0.858 & 794 & 681 \\
\hline 1111 & 67.21 & 0.885 & 794 & 703 \\
\hline 1165 & 66.10 & 0.936 & 794 & 743 \\
\hline 1243 & 66.10 & 0.936 & 794 & 743 \\
\hline 1352 & 64.16 & 0.968 & 499 & 768 \\
\hline 1554 & 64.91 & 0.972 & 407 & 485 \\
\hline 1622 & 63.50 & 0.982 & 322 & 400 \\
\hline 1952 & 60.16 & 1.155 & 318 & 372 \\
\hline 2076 & 54.34 & 1.247 & 167 & 397 \\
\hline 2288 & 52.61 & 1.308 & 167 & 218 \\
\hline 2434 & 54.54 & 1.245 & 175 & 218 \\
\hline 2602 & 54.75 & 1.226 & 76 & 93 \\
\hline 2939 & 59.51 & 1.073 & 76 & 82 \\
\hline 3009 & 57.98 & 1.105 & 76 & 84 \\
\hline 3065 & 60.94 & 1.094 & 76 & 83 \\
\hline 3247 & 61.69 & 1.050 & 76 & 80 \\
\hline 3443 & 57.45 & 1.166 & 41.5 & 48 \\
\hline 3529 & 56.52 & 1.191 & 41.5 & 49 \\
\hline 3937 & 58.68 & 1.145 & 41.5 & 48 \\
\hline 4036 & 58.68 & 1.153 & 41.5 & 48 \\
\hline 4102 & 55.96 & 1.189 & 41.5 & 49 \\
\hline 4202 & 53.49 & 1.288 & 41.5 & 53 \\
\hline 4278 & 52.61 & 1.313 & 41.5 & 55 \\
\hline 4338 & 51.46 & 1.350 & 41.5 & 56 \\
\hline 4461 & 53.05 & 1.254 & 41.5 & 52 \\
\hline 4997 & 55.16 & 1.220 & 41.5 & 51 \\
\hline 4560 & 55.16 & 1.238 & 41.5 & 51 \\
\hline 4720 & 59.18 & 1.122 & 41.5 & 47 \\
\hline 4821 & 56.90 & 1.134 & 41.5 & 47 \\
\hline 4965 & 57.26 & 1.188 & 41.5 & 49 \\
\hline 5136 & 54.55 & 1.250 & 41.5 & 52 \\
\hline 5369 & 54.55 & 1.277 & 41.5 & 53 \\
\hline 5422 & 32.43 & 1.838 & \multicolumn{2}{|c|}{ Carbonate turbidites } \\
\hline 5710 & 36.31 & 1.745 & \multicolumn{2}{|c|}{ Carbonate turbidites } \\
\hline 5872 & 33.77 & 1.795 & \multicolumn{2}{|c|}{ Carbonate turbidites } \\
\hline 6009 & 41.86 & 1.634 & \multicolumn{2}{|c|}{ Carbonate turbidites } \\
\hline 6070 & 35.90 & 1.750 & \multicolumn{2}{|c|}{ Carbonate turbidites } \\
\hline 6277 & 34.21 & 1.816 & \multicolumn{2}{|c|}{ Carbonate turbidites } \\
\hline 6361 & 33.77 & 1.788 & \multicolumn{2}{|c|}{ Carbonate turbidites } \\
\hline
\end{tabular}

a Dadey, 1983

b Calculated from water contents and wet-bulk density data (Dadey, 1983):

$$
\rho_{\mathrm{D}}=\rho_{\mathrm{W}}\left(1-X_{\mathrm{W}}\right) / 100
$$

when $\rho_{\mathrm{D}}$ is the dry-bulk density, $\rho_{\mathrm{W}}$ is the wet-bulk density, and $X_{\mathrm{W}}$ is the water content.

c Heath et al., 1983

d Calculated from dry-bulk densities and sedimentation rates, see text.

in Hole 576A shows low and nearly constant accumulation rates until the middle Neogene Period. About 15 m.y. ago, quartz accumulation began to increase slightly. Two large increases in accumulation took place about 5 and $2.5 \mathrm{~m} . \mathrm{y}$. ago. The timing of the increases is very similar to increases in quartz accumulation in Core LL44GPC3 (Fig. 4, Leinen and Heath, in press). The principal difference between the two sites is in the absolute value of the accumulation rate. In Hole 576A quartz has accumulated at roughly four times the rate in Core LL44-GPC3 for most of the Pliocene and Pleistocene epochs ( 5 m.y. ago to present).

The initial increase in quartz accumulation from the low mid-Tertiary values in Core LL44-GPC3 occurred about $20 \mathrm{~m}$.y. ago. Because age determinations are nec- essary for the accumulation-rate calculation, the values are dependent on stratigraphy. Correlation of ichthyolith ranges suggests that the increase in quartz accumulation in Core LL44-GPC3 is actually coincident with that in Hole 576. These increases could be caused by changes in the positions of the sites with respect to the westerlies (i.e., source mineralogy) or changes in the amount or efficiency of transport from land, but their association with changes in the quartz content and clay mineralogy (see Leinen and Heath, 1981; Lenotre et al., this volume) argues strongly that they reflect the passage of the core sites into the influence of the westerlies rather than solely a change in transport efficiency.

During the late Neogene, the quartz accumulation rate in Hole 576A increased markedly between 4 and 6 m.y. 
Table 3. Quartz accumulation rates of Hole 576A samples.

\begin{tabular}{|c|c|c|c|c|}
\hline $\begin{array}{l}\text { Core-Section } \\
\text { (interval in cm) }\end{array}$ & $\begin{array}{c}\text { Sample } \\
\text { depth } \\
\text { (cm) }\end{array}$ & $\begin{array}{l}\text { Quartz } \\
(\%)\end{array}$ & $\begin{array}{l}\mathrm{Age}^{\mathrm{a}} \\
\text { (m.y.) }\end{array}$ & $\begin{array}{c}\text { Quartz } \\
\text { accumulation } \\
\text { rate }^{\mathrm{b}} \\
\left(\mathrm{g} / \mathrm{cm}^{2} / \mathrm{m} . \mathrm{y} .\right)\end{array}$ \\
\hline $1-1,21-25$ & 23 & 16.63 & 0.26 & 237.0 \\
\hline $1-3,81-85$ & 383 & 18.11 & 0.53 & 254.0 \\
\hline $1-6,80-83$ & 831 & 15.52 & 0.87 & 166.0 \\
\hline $2-3,47-50$ & 1219 & 17.35 & 1.32 & 129.0 \\
\hline $3-1,47-50$ & 1869 & 13.06 & 2.56 & 47.0 \\
\hline $3-3,70-73$ & 2191 & 8.87 & 3.59 & 33.0 \\
\hline $3-4,117-120$ & 2389 & 11.66 & 4.39 & 37.0 \\
\hline $3-5,127-130$ & 2549 & 9.02 & 5.86 & 8.3 \\
\hline $3-6,110-113$ & 2681 & 14.64 & 7.60 & 14.0 \\
\hline $4-1,50-53$ & 2821 & 10.92 & 9.44 & 10.0 \\
\hline $4-2,103-106$ & 3025 & 8.57 & 12.13 & 7.2 \\
\hline $4-3,98-101$ & 3169 & 5.81 & 14.03 & 4.8 \\
\hline $4-4,104-107$ & 3325 & 5.86 & 16.35 & 2.7 \\
\hline $4-5,20-23$ & 3391 & 4.25 & 17.94 & 2.0 \\
\hline $4-6,60-63$ & 3581 & 5.31 & 25.00 & 2.6 \\
\hline $5-1,87-90$ & 3809 & 5.16 & 28.00 & 2.5 \\
\hline $5-2,40-43$ & 3911 & 1.76 & 31.00 & 0.8 \\
\hline $5-3,30-33$ & 4051 & 2.64 & 34.00 & 1.3 \\
\hline $5-5,137-140$ & 4459 & 4.67 & 44.00 & 2.4 \\
\hline $5-6,130-133$ & 4601 & 2.88 & 47.00 & 1.4 \\
\hline $5-7,25-28$ & 4646 & 6.18 & 48.00 & 3.0 \\
\hline $6-1,90-93$ & 4761 & 3.96 & 51.00 & 1.9 \\
\hline $6-2,47-50$ & 4869 & 4.21 & 54.00 & 2.0 \\
\hline $6-3,93-96$ & 5065 & 4.81 & 58.00 & 2.4 \\
\hline $6-4,11-14$ & 5132 & 6.12 & 60.00 & 3.2 \\
\hline $6-5,12-15$ & 5283 & 5.41 & 64.00 & 2.8 \\
\hline $6-5,127-13$ & 5399 & 4.54 & 66.00 & 2.4 \\
\hline $6-6,17-20$ & 5439 & 5.29 & \multicolumn{2}{|c|}{ Carbonate turbidites } \\
\hline $6-7,22-25$ & 5593 & 3.91 & \multicolumn{2}{|c|}{ Carbonate turbidites } \\
\hline $7-1,137-140$ & 5759 & 4.16 & \multirow{2}{*}{\multicolumn{2}{|c|}{ Carbonate turbidites }} \\
\hline $7-2,22-25$ & 5793 & 5.50 & Carbonate turbidites & \\
\hline $7-3,17-20$ & 5939 & 6.46 & \multicolumn{2}{|c|}{ Carbonate turbidites } \\
\hline $7-3,35-38$ & 5946 & 3.51 & \multicolumn{2}{|c|}{ Carbonate turbidites } \\
\hline
\end{tabular}

a Determined by interpolation between paleomagnetic datums for $0-24.76 \mathrm{~m}$ and by interpolation between ichthyolith datums for $24.76-54.0 \mathrm{~m}$.

b Mass accumulation rates for sample depths were interpolated from data in Table 2.

ago. Similar increases in eolian accumulation over this interval have been calculated by Rea and Janecek (1982) from DSDP Sites 305 and 310 (Fig. 1). They attributed the increase to an influx of volcanic ash and pumice associated with the late Miocene to early Pliocene volcanic episode (Kennett and Thunell, 1975; Kennett, 1977). There is, however, no significant ash component in sediments of that age in either Core LL44-GPC3 or Hole 576A. Therefore, the increase cannot be attributed to volcanic activity in these cores.

It is likely that there is aliasing in the temporal record of quartz concentration. Two Neogene samples have a much lower quartz content than those above and below them. If these points are ignored, the late Neogene record simply records an accelerating increase in mineralaerosol accumulation with increasing Miocene and Pliocene aridity (Wolfe and Hopkins, 1967) caused by global cooling (Savin, 1977; Kennett, 1977; Woodruff et al., 1981) or movement of the core site into the influence of the westerlies.

The Hole 576A quartz accumulation does highlight the dramatic increase in mineral-aerosol accumulation that occurred after the onset of Northern Hemisphere glaciation 2.5 m.y. ago (Shackleton et al., 1983; Prell, 1982). Quartz accumulation increased from about 50 to
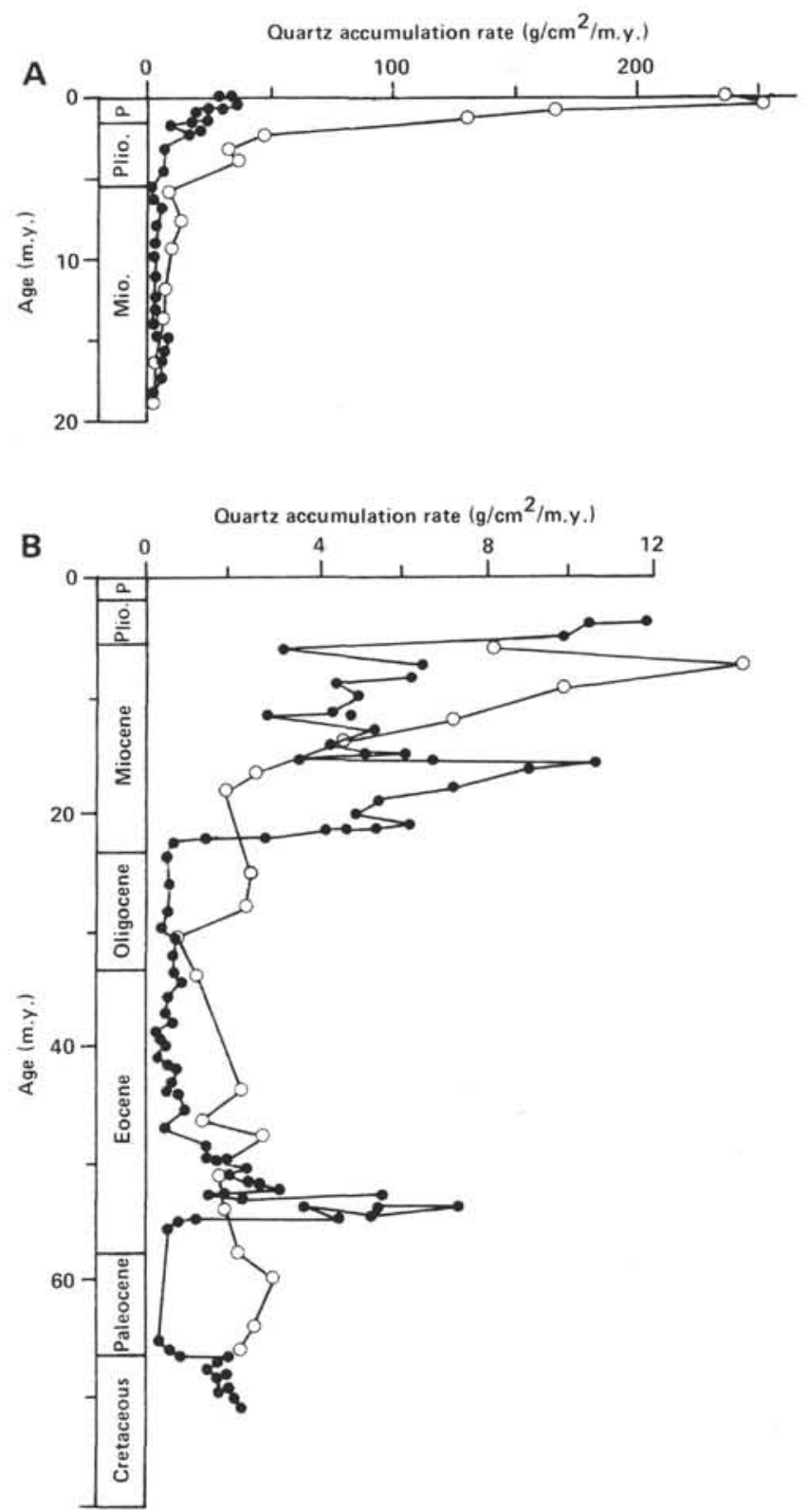

Figure 4. Quartz accumulation rate in Hole 576A and Core LL44GPC-3. Filled circles are Core LL44-GPC-3 data; open circles are Hole 576A data. A. Neogene rates, B. Pre-Pleistocene rates plotted on an expanded scale.

$130 \mathrm{~g} / \mathrm{cm}^{2} / \mathrm{m} . y_{.}$, and total sediment accumulation increased from about 400 to $700 \mathrm{~g} / \mathrm{cm}^{2} / \mathrm{m}$.y. at that time. Late Pleistocene quartz accumulation rates are about 250 $\mathrm{g} / \mathrm{cm}^{2} / \mathrm{m}$.y., five times their preglacial rates. The rather small changes in grain size of both the total eolian mineral assemblage in Hole 576 (Janecek, this volume) and the quartz in Core LL44-GPC3 (Janecek and Rea, in press) suggest that these changes are due primarily to changes in climate, which made more material available for transport, rather than to changes in wind "vigor."

\section{CONCLUSIONS}

The quartz record in Hole 576A reflects changes in the source and amount of mineral aerosol being depos- 
ited in the northwest Pacific with time. When the Hole $576 \mathrm{~A}$ quartz record is compared with other long records of mineral-aerosol deposition (Core LL44-GPC3), a strong uniformity in the composition of the mineral aerosol across the North Pacific and an equilibrium mineral assemblage in the aerosol are indicated. The temporal record of quartz content and accumulation rate suggests that Hole 576A entered the influence of material transported by the westerlies about $15 \mathrm{~m}$.y ago and that rates of sediment deposition have increased since then. Only a dramatic change in quartz accumulation about 2.5 m.y. ago can be clearly related to a climatic event, but it is likely that the gradual increase in quartz accumulation through the Miocene and early Pliocene epochs is a result of increasing Northern Hemisphere aridity and intensified atmospheric activity associated with global cooling and an increase in the equator-to-pole temperature gradient.

\section{ACKNOWLEDGMENTS}

The careful X-ray diffraction analyses for this study were performed by Tammy King Walsh and Sandra Furda. The work was supported by the Subseabed Disposal Program of the Department of Energy (Contract No. SAN 26-6610) administered by Sandia National Laboratories. I would like to thank Les Shephard for sampling the cores and G. Ross Heath for providing the paleomagnetic reversal stratigraphy before publication and for reviewing the manuscript. The manuscript was typed by Kathy Hazard. It benefited from reviews by Thomas Janecek and Ted Moore.

\section{REFERENCES}

Dadey, K., 1983. Consolidation parameters of a northwest Pacific clay site, DSDP Site 576A [M. S. thesis]. University of Rhode Island, Kingston.

Dauphin, J. P., 1983. Eolian quartz granulometry as a paleowind indicator in the northeast equatorial Atlantic, north Pacific , and southeast equatorial Pacific [Ph.D. dissert.]. University of Rhode Island, Kingston.

Doyle, P., 1980. Seabed disposal program: improvement of ichthyolith stratigraphy for giant piston Core 3 , progress report for period November 1, 1979-September 30, 1980. In Hinga, K. (Ed.), Subseabed Disposal Program Annual Report, January to December, 1980, Vol. 2, Pt. 2, Appendices, SAN81-1095/II , July 1981, pp. 325-341. 1983. Ichthyolith stratigraphy in the Pacific. EOS, Trans. Am. Geophys. Union (Fall 1983 Ann. Mtg.). (Abstract)

Doyle, P., and Riedel, W. R., 1979. Cretaceous to Neogene ichthyoliths in a giant piston core from the Central North Pacific. Micropaleontology, 25:337-364.

Duce, R. A., Unni, C. K., Ray, B. J., Prospero, J. M., and Merrill, J. T., 1980. Long-range atmospheric transport of soil dust from Asia to the tropical North Pacific: Temporal variability. Science, 209: 1522-1524.

Ellis, D. B., and Moore, T. C., Jr., 1973. Calcium carbonate opal and quartz in Holocene pelagic sediments and the calcite compensation level in the south Atlantic Ocean. J. Mar. Res., 31:210-227.

Gillette, D. A., 1981. Production of dust that may be carried great distances. In Pewe, T. L. (Ed.), Desert Dust: Origin, Characteristics, and Effects on Man. Geol. Soc. Am. Spec. Pap., 186:11-26.

Griffin, J. J., Windom, H., and Goldberg, E. D., 1968. The distribution of clay minerals in the world ocean. Deep-Sea Res., 15:433-459.

Heath, G. R., Moore, T. C., Jr., Opdyke, N. D., and Dauphin, J. P., 1973. Distribution of quartz, opal, calcium carbonate and organic carbon in Holocene, 600,000 and Brunhes/Matuyama age sediments of the north Pacific. Geol. Soc. Am. Abstr. Prog., 5:662 (Abstract)

Heath, G. R., and Pisias, N. G., 1979. A method for the quantitative estimation of clay mineral in north Pacific deep-sea sediments. Clays Clay Mineral., 27(3):175-184.
Heath, G. R., Rea, D. K., and Pisias, N. G., 1983. Paleomagnetic stratigraphy and sedimentation rates of pelagic clays from the western North Pacific. EOS, Trans. Am. Geophys. Union, Fall 1983 Ann. Mtg., 741.

Janecek, T., and Rea, D. K., in press. Variations in atmospheric circulation associated with the onset of Northern Hemisphere glaciation. Mar. Geol.

Kennett, J. P., 1977. Cenozoic evolution of Antarctic glaciation, the circum-Antarctic Ocean, and their impact on global paleoceanography. J. Geophys. Res., 82(27):3843-3860.

Kennett, J. P., and Thunell, R. C., 1975. Global increase in Quaternary explosive volcanism. Science, 187:497-503.

Kolla, V., and Biscaye, P. E., 1977. Distribution and origin of quartz in the sediments of the Indian Ocean. J. Sediment. Petrol., 47(2): 642-649.

Kyte, F. T., and Wasson, J., in press. The Cretaceous-Tertiary boundary in GPC3, an abyssal clay section. Geochim. Cosmochim. Acta.

Leinen, M., and Heath, G. R., 1981. Sedimentary indicators of atmospheric circulation in the Northern Hemisphere during the Cenozoic. Paleogeogr., Paleoclimatol., Paleoecol., 36:1-21. , in press. Chemical signatures in Cenozoic sediments from the central North Pacific and their oceanographic significance. Geochim. Cosmochim. Acta.

McCauley, J. F., Breed, C. S., Grolier, M. J., and MacKinnon, D. J., 1981. The U.S. dust storm of February 1977. In Pewe, T. L. (Ed.), Desert Dust: Origin, Characteristics, and Effect on Man. Geol. Soc. Am., Spec. Pap., 186:123-148.

Molina-Cruz, A., and Price, P., 1977. Distribution of opal and quartz on the ocean floor of the subtropical southeastern Pacific. Geolo$g y, 5: 81-84$.

Moore, T. C., Jr., and Heath, G. R., 1978. Sea-floor sampling techniques. In Riley, J. P., and Chester, R. (Eds.), Chemical Oceanography, (2nd ed., Vol. 7, Chap. 36): New York (Academic Press), 75-126.

Parkin, D. W., 1974. Trade winds during the glacial cycles. Proc. $R$. Soc. London, Ser. A, 337:73-100.

Parkin, D. W., and Padgham, R. C., 1975. Further studies on trade winds during the glacial cycles. Proc. R. Soc. London, Ser. A, 346: 245-260.

Pewe, T. L., Pewe, E. A., Pewe, R. H., Journaux, A., and Slatt, R. M., 1981. Desert dust: Characteristics and rates of deposition in central Arizona, U.S.A. In Pewe, T. L., (Ed.), Desert Dust: Origin, Characteristics, and Effect on Man. Geol. Soc. Am. Spec. Pap., 186:169-190.

Pisias, N. G., and Leinen, M., 1983. Late Pleistocene variability of the northwest sector of the Pacific Ocean. In Berger, A., and Imbrie, J. (Co-chairmen), Int. Symp. Milankovitch and Climate: Understanding the Response to Orbital Forcing, Pt. 1, 307-330.

Prell, W., 1982. A reevaluation of the initiation of Northern Hemisphere glaciation at 3.2 m.y.: New isotopic evidence. Geol. Soc. Am. Abstr. Progr., 14(7):592. (Abstract)

Prince, R. A., 1978. Southward motion of the Hawaiian hotspot between 42 and 25 MYPB. Geol. Soc. Am. Abstr. Progr., 10:474. (Abstract)

Prince, R. A., Heath, G. R., and Kominz, M., 1980. Paleomagnetic stratigraphies of central north Pacific sediment cores: Stratigraphy sedimentation rates and the origin of magnetic instability. Geol. Soc. Am. Bull., 91(II):1789-1835.

Rea, D. K., and Janecek, T. R., 1981. Late Cretaceous history of Eolian deposition in the Mid-Pacific mountain, central North Pacific Ocean. Paleogeogr., Paleoclimatol., Paleoecol., 36:55-67.

1982. Late Cenozoic changes in atmospheric circulation deduced from North Pacific eolian sediments. Mar. Geol., 49:149-167.

Rex, R. W., and Goldberg, E. D., 1958. Quartz content of pelagic sediments of the Pacific Ocean. Tellus, 10:153-159.

Rex, R. W., Syers, J. K., Jackson, M. L., and Clayton, R. N., 1969. Eolian origin of quartz in soils of Hawaiian Islands and in Pacific pelagic sediments. Science, 163:277-279.

Savin, S. M., 1977. The history of the Earth's surface temperature during the past 100 million years. Annu. Rev. Earth Planet. Sci., 5:319-355.

Schramm, C. T., 1983. Changes in atmospheric and oceanic circulation in the east equatorial Pacific during the late Quaternary [M.S. thesis]. University of Rhode Island, Kingston. 
Shackleton, N. J., Backman, J., Kent, D., Imbrie, J., Pestiaux, P., et al., 1983. The evolution of climate response to orbital forcing: Results over three million years from DSDP Site 552A. In Berger, A., and Imbrie, J. (Co-chairmen), Internat. Symp. Milankovitch and Climate: Understanding the Response to Orbital Forcing. (abstract)

Thiede, J., 1979. Wind regimes over the late Quaternary southwest Pacific Ocean. Geology, 7:259-262.

Till, R., and Spears, D. A., 1969. The determination of quartz in sedimentary rocks using an X-ray diffraction method. Clays Clay Mineral., 17:323-327.

van Andel, T. H., Heath, G. R., and Moore, T. C., Jr., 1975. Cenozoic history and paleoceanography of the Central Equatorial Pacific Ocean. Mem. Geol. Soc. Am., 143:134.
Windom, H. L., 1969. Atmospheric dust records in permanent snowfields: Implications to marine sedimentation. Geol. Soc. Am. Bull., 80:761-782.

1975. Eolian contributions to marine sediments. J. Sediment. Petrol., 45:520-529.

Wolfe, J. A., and Hopkins, D. M., 1967. Climatic changes recorded by Tertiary land floras in northwestern North America: Tertiary correlations and climatic changes in the Pacific. 11th Pacific Science Congr., Tokyo, Symp., 25:67-76.

Woodruff, F., Savin, S. M., and Douglas, R. G., 1981. Miocene stable isotope record: A detailed deep Pacific Ocean study and its paleoclimatic implications. Science, 212:665-668.

Date of Initial Receipt: 3 November 1983 Date of Acceptance: 14 June 1984 